NOTE

\title{
Assessment of an underwater biopsy probe for collecting teleost fish tissue samples
}

\author{
R. D. Evans* \\ School of Marine \& Tropical Biology and Centre of Excellence in Coral Reef Studies, James Cook University, \\ Townsville, 4811 Queensland, Australia
}

\begin{abstract}
This study tested the efficiency of an underwater biopsy probe designed to remove tissue samples for molecular analysis from small- to medium-sized $(15$ to $70 \mathrm{~cm})$ marine teleost fish in the field. The probe was fired at lower and higher power from a $76 \mathrm{~cm}$ rubber-propelled spear gun. Two species were targeted: Plectropomus maculatus and Lutjanus carponotatus. The results were highly successful for P. maculatus, with $>80 \%$ of hits at lower and higher power resulting in sufficient tissue extraction for molecular analysis. The results were less consistent for L. carponotatus at lower power $(45 \%)$ due to the relatively large scales of the fish. At higher power the success rate increased to $73 \%$. In $97 \%$ of cases, fish swam away rapidly with only minor lesions and showing no signs of incapacitation. Furthermore, aquarium trials showed no post-impact mortality after a 2 wk period. Therefore, the biopsy probe tested in this study is considered successful when the spear gun is fired at the correct power for the target species. This will allow for easier tissue sample collection from small- to medium-sized teleost fish for population and phylogenetic studies than previous methods of killing or capturing individuals.
\end{abstract}

KEY WORDS: Underwater biopsy probe $\cdot$ Tissue sampling $\cdot$ Teleost fish $\cdot$ Plectropomus maculatus Lutjanus carponotatus $\cdot$ Molecular analysis

\section{INTRODUCTION}

Collecting tissue samples from mobile marine organisms without capturing or killing them is difficult. Until recently, most tissue sample collections required the capture of an organism to remove a sample of skin or flesh. Spear guns or poisons are commonly used to kill smaller, manageable animals. Traps, nets or fishing lines are used to capture animals of all sizes to remove a tissue sample. The latter process is intended to be non-fatal, although barometric pressure changes and stresses on the organism may lead to fatality (Bartholomew \& Bohnsack 2005). New techniques of collecting tissue samples that decrease or eliminate fatalities of mobile marine species, such as teleost fish, are required.

Various non-fatal techniques are used to target large megafauna, such as cetaceans and reptiles that surface to breath, including crossbow, poles, above-water spear guns or modified rifles (Krutzen et al. 2002, Borrell et al. 2004, Dalebout et al. 2006, Spinsanti et al. 2006). Equivalent underwater techniques have only recently been developed for sharks using a biopsy probe fitted to a spear gun (Robbins 2006). The diver fires a spear-mounted probe at sharks underwater to remove a small core of tissue for molecular analysis; the sharks survive with only a small hole. Opportunistic use of the shark biopsy probe on 2 larger teleost fish, Cheilinus undulatus (Ruppell, 1835) and Bulbometapon muricatum (Valenciennes, 1840), also proved successful (Robbins 2006). However, a technique has not been trialed for small- to medium-sized teleost fish $(15$ to $70 \mathrm{~cm})$.

Several collection methods are used for teleost fish depending on their size and the information required. Spear guns are typically used to kill fish and collect genetic samples in conjunction with collection of gonads and otoliths for reproductive, age determina- 
tion and growth studies. Hook-and-line fishing techniques and nets are employed to ensure survival of the targeted species. However, both of these processes may be fatal, via barotrauma or physical injury (Diggles \& Ernst 1997). A biopsy probe for small- to medium-sized fish may alleviate any fishing-induced mortality and enable selectivity of individuals or size classes in a population. Potential uses for the biopsy probe may include fishery-independent genetic stock assessments; population and phylogenetic studies of rare endangered species or species within marine protected areas; and parentage analysis from spawning aggregation sites. The success of such a tool would be dependent on the researchers' ability to approach the target species. A tool of this nature may not be efficient for fast-moving, pelagic species. However, suitably sized fish that are demersally attached or home-ranging would be appropriate target species.

A probe designed to collect tissue samples for molecular analysis, without capturing or killing the fish, was tested on 2 coral reef fish species, Plectropomus maculatus (Bloch, 1790) and Lutjanus carponotatus (Richardson, 1842). These 2 species differ in certain aspects of their behaviour and morphology. P. maculatus grows to $75 \mathrm{~cm}$, has very small scales and is a curious fish that will often approach a non-aggressive diver. In contrast, L. carponotatus grows to $45 \mathrm{~cm}$, has relatively large scales and is very nervous around divers. This study documents the efficiency and the inherent problems of using a particular biopsy probe on 2 small- to medium-sized teleost fish species with different behaviours and morphological characteristics.

\section{MATERIALS AND METHODS}

The biopsy probe tested in this study (Fig. 1) used a configuration similar to that of the 2 probes (Types I and II) developed by Robbins (2006), with 3 major design changes. Firstly, the design of Robbins' 2 types (I, II) were combined, using the barrel of Type I and the dental brooches of Type II (Fig. 1). In this study, the 2 dental brooches were twisted around each other, inserted into the barrel of the probe and both were secured in a stainless steel spear-shaft adaptor with a split pin (Fig. 1). Secondly, all dimensions were reduced to minimize penetration into the smaller fish. Thirdly, notch orientation was inverted from rearward- to forward-facing (Fig. 1) to account for size and morphology differences between sharks and teleost fish. Shark flesh is much firmer than teleost fish and the relatively large size of sharks allows for a direct entry core to be removed. In contrast, the impact with a small teleost fish is more of a scraping motion through the soft flesh, so forward-facing notches increased tissue retention.
The adaptor was screwed onto a spear-shaft that was fired by a rubber-propelled $76 \mathrm{~cm}$ spear gun, with standard $18 \mathrm{~mm}$ diameter spear rubbers. The reduced power and range ( $2 \mathrm{~m}$ max. reach from diver) of such a small spear gun helped to ensure the accuracy and impact of the biopsy probe. The power of the spear guns was not measured in absolute terms. Initially the guns were powered at a minimal strength (lower power) to reduce the chance of injury to the fish, which provided mixed results for the 2 species. For better consistency the spear guns were adjusted to a greater power (higher power). Therefore, the terms 'lower power' and 'higher power' are relative, not absolute.

Samples were collected in the Whitsunday Islands $\left(20^{\circ} 05.600^{\prime} \mathrm{S}, 148^{\circ} 56.992^{\prime} \mathrm{E}\right)$, Great Barrier Reef, Australia. Scuba divers hunted the fish or baited the water with pilchards to attract them. Divers targeted the dorsal posterior section of the fish to avoid serious injury to the head and vital organs. Tissue collection success rate was recorded based on the number of tissue samples collected versus the number of hits for each species. After a successful tissue extraction, the probe adaptors with probe were unscrewed underwater and placed in specimen jars and labeled. Divers typically carried up to 15 probes on a dive. Post dive, the samples were extracted from the probes and placed directly in $80 \%$ ethanol. To reduce the chances of cross infection between individuals, and contamination of samples, all probes were soaked in $42 \mathrm{~g} \mathrm{l}^{-1}$ solution of sodium hypochlorite (household bleach) for $30 \mathrm{~min}$ before rinsing in fresh water.

All tissue samples were weighed to 4 decimal places (wet weight in grams) and DNA was subsequently extracted from the tissues using the method developed by Elphinstone et al. (2003). Using this method, DNA

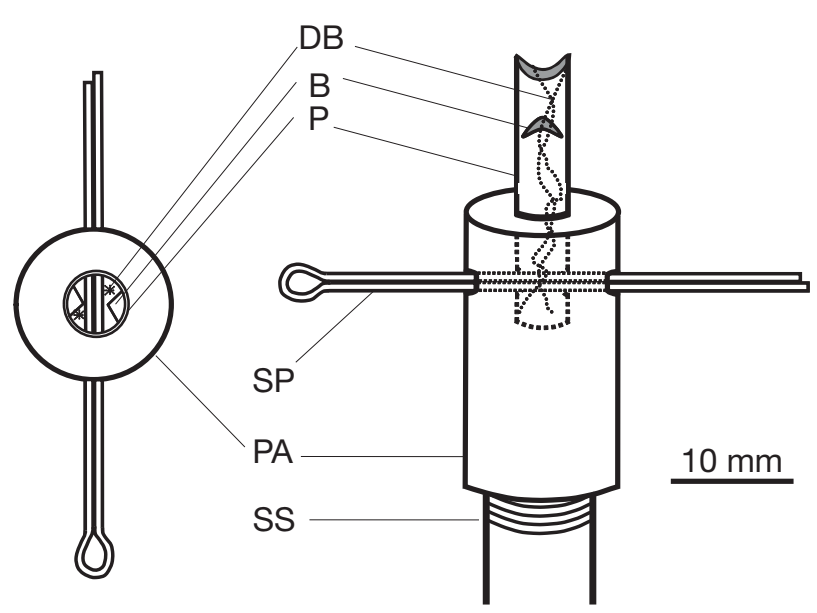

Fig. 1. Underwater biopsy probe for small- to medium-sized teleost fish. DB: dental brooches; B: forward-facing barb; P: probe; SP: split pin; PA: probe adaptor; SS: spear shaft 
was successfully extracted from a wet tissue weight of $0.0007 \mathrm{~g}$ of flesh and/or skin. However, DNA could not be extracted from the scales of these 2 species using this particular method. Therefore every sample greater than $0.0007 \mathrm{~g}$ of flesh/skin was considered a successful use of a biopsy probe.

Survival rate. In situ, the fish were observed for any adverse effects of the impact of the biopsy probe. Observation time was minimal, as all but a few fish departed immediately. Therefore a tank experiment was set up to observe the fish for 2 wk after probing. Lutjanus carponotatus were used to test post-impact effects of the biopsy probe because they are the smaller of the 2 species and impact from the probe would obviously create a greater wound relative to body size. Nine $L$. carponotatus individuals were caught from Pelorus Island, Palm Island Group, Great Barrier Reef, using hook and line. Three individuals were placed in 3 separate $600 \mathrm{l}$ tanks to test mortality rates caused by the probe. After a period of $4 \mathrm{~d}$ acclimatization, all fish were measured (in $\mathrm{mm}$ ) and injected with a T-bar tag for identification. One fish from each tank was scraped with a probe in the upper half of the caudal region, one scraped near the dorsal fin and the third fish, the control, was only measured and tagged. Fish were subsequently held in the tanks for $15 \mathrm{~d}$. Daily observations of feeding rate and general health were recorded throughout the experiment. At the end of $15 \mathrm{~d}$ the fish were measured and the scratches were observed for signs of infection, or partial or complete healing. All fish were released back to the reef.

\section{RESULTS}

The success of the biopsy probe was species-specific, particularly with regards to differences in scale size of the species, and also depended upon the power of the spear gun. Behaviour also may have played a role in the ability to hit and retain a tissue sample from the 2 species. Plectropomus maculatus were often curious towards the diver. This made it easy to ensure an accurate shot. In contrast, it was difficult to aim at the fastmoving, cautious Lutjanus carponotatus, and thus achieve a successful hit. Overall, the probe was only $63 \%$ successful in collecting a tissue sample from $L$. carponotatus, but $80 \%$ successful for $P$. maculatus (Table 1).

At lower power the relatively larger scales of Lutjanus carponotatus reduced the ability of the probe to extract and retain fish flesh (Table 1): 9 out of 20 hits $(45 \%)$ were successful in collecting $L$. carponotatus tissue for DNA processing. Seven of the unsuccessful $L$. carponotatus tissue sample extractions consisted only of scales. At high power the probe collected ample $L$. carponotatus tissue samples 28 times from 38 hits (73\%). Plectropomus maculatus has relatively smaller scales that did not impede the biopsy probe. Successful DNA tissue collection was achieved for the probe at the lower $(81 \%)$ and higher power $(84 \%)$ settings of the spear gun (Table 1). Average wet weight of tissue samples collected from L. carponotatus was $0.014 \pm$ $0.002 \mathrm{~g}$ (mean $\pm \mathrm{SE}$ ) and from P. maculatus was $0.02 \pm$ $0.003 \mathrm{~g}$. There was no significant difference in the average wet weight of tissue collected from both species (1-way ANOVA: $p=0.06 ; 1,84 \mathrm{df}$ ).

In situ observations of the fish after probing were insufficient to fully understand the effects of probe impact on individual fish. Of the 105 fish probed, only 3 mortalities were recorded ( $2.8 \%$ ) due to the spearing process. All 3 mortalities in situ occurred using the higher power setting on the spear gun (Table 1). In these cases, the probe was miss-fired and struck the head or the ventral nerve of the fish. The vast majority of fish swam away rapidly, but in cases where pilchards were used as bait to attract the target species, several individuals swam back into the feeding frenzy and continued their normal feeding behaviour.

In the tank experiment, all Lutjanus carponotatus individuals were eating approximately 2 small pieces of pilchard per day before the probe trial. Post impact, the fish returned to their normal 'tank' feeding behaviour the following day. After $9 \mathrm{~d}$ each fish was consum-

Table 1. Lutjanus carponotatus and Plectropomus maculatus. Success rates of tissue extraction by the biopsy probe. Totals are given in bold

\begin{tabular}{|c|c|c|c|c|c|c|}
\hline Species & $\begin{array}{l}\text { No. of } \\
\text { hits }\end{array}$ & $\begin{array}{l}\text { No. with } \\
\text { tissue }\end{array}$ & $\begin{array}{l}\% \text { tissue } \\
\text { success }\end{array}$ & $\begin{array}{l}\text { DNA success } \\
(>0.0007 \mathrm{~g})\end{array}$ & $\begin{array}{l}\% \text { DNA } \\
\text { success }\end{array}$ & Mortality \\
\hline Lutjanus carponotatus & 58 & 46 & 79 & 37 & 63 & 2 \\
\hline Lower power & 20 & 17 & 85 & 9 & 45 & 0 \\
\hline Higher power & 38 & 29 & 76 & 28 & 73 & 2 \\
\hline Plectropomus maculatus & 47 & 39 & 83 & 39 & 83 & 1 \\
\hline Lower power & 22 & 18 & 81 & 18 & 81 & 0 \\
\hline Higher power & 25 & 21 & 84 & 21 & 84 & 1 \\
\hline
\end{tabular}


ing up to 3 pieces per day. At the end of $15 \mathrm{~d}$ all lesions but 1 had healed. No scales had grown back at the site of the lesions in all individuals, but more importantly, no infections occurred during the experiment. All 9 fish were released back to the reef successfully.

\section{DISCUSSION}

The use of the fish biopsy probe to remove small samples of tissue from highly mobile species of marine teleost fish was successful, with results varying depending upon the scale size of the target species. High tissue retention rates and low mortality levels demonstrate the utility of the biopsy probe for endangered species of fish or on species within marine protected areas. Conventional tissue collection methods for marine teleost fish are expensive and often detrimental to the health of the sampled species. Although the technique used here is useful only for genetic population studies, rather than for age and/or reproductive studies, it does provide a highly selective and relatively fast method of tissue collection for molecular studies. For example, tissue samples from this trial have been used in population and phylogenetic studies of both Plectropomus maculatus and Lutjanus carponotatus on the inner-shelf of the Great Barrier Reef (author's unpubl. data).

It should be noted that the small size of the tissue sample collected requires extreme care at all stages from actual impact to DNA extraction. Care must be taken to ensure that enough tissue is removed and preserved to enable successful DNA extraction. Furthermore, if the entire sample of a rare individual has to be used in the DNA extraction, there is no margin for error. DNA was extracted from most samples, but not all. Unsuccessful hits usually resulted in scales drifting in the water column. If these could be used, the success rate would increase. DNA has been extracted from Epinephelus daemeli scales (L. van Herwerden pers. comm.), but it is unclear whether it was the genetic technique used or because there may have been enough skin attached to the relatively large scale of this species which enabled successful molecular analysis. Smaller species of fish have much smaller scales and inherently less or no skin attached to the scale. Further work is needed in this area.

The biopsy probe can be used on any size/power spear gun, but the results show that the correct power and range of the apparatus is very important to the success rate. Understanding the morphology and behaviour of the target species will help to determine the size of the probe and the spear gun power, to increase tissue retention and to minimize fish injury. The fish in this study were resilient to small scratches; Lutjanus carponotatus did not suffer infections in the laboratory trial and in situ some individuals of both species returned to feeding within minutes of impact from the biopsy probe. However, sub-lethal effects on long term growth or reproduction were not ascertained; this is important to know, particularly if fish are targeted on spawning aggregations.

Acknowledgements. I thank GBRMPA for their Science for Management Award. I also thank R. Gegg for constructing the probes and Orpheus Island Research Station, Kalinda, P. Costello, P. Mantel, W. Robbins, N. Taylor and D. Williamson for assistance in the field. Thanks to P. Mantel and G. Russ for useful comments on the manuscript. This study was conducted in accordance with James Cook University ethics approval \#A1130. This study was funded by a 'Science for Management Award' from the Great Barrier Reef Marine Park Authority; the Queensland Government's 'Growing the Smart State PhD Funding Program'; and the Australian Coral Reef Society Terry Walker Prize.

\section{LITERATURE CITED}

Bartholomew A, Bohnsack JA (2005) A review of catch-andrelease angling mortality with implications for no-take reserves. Rev Fish Biol Fish 15:129-154

Borrell A, Cantos G, Pastor T, Aguilar A (2004) Levels of organochlorine compounds in spotted dolphins from the Coiba archipelago, Panama. Chemosphere 54:669-677

- Dalebout ML, Ruzzante DE, Whitehead H, Oien NI (2006) Nuclear and mitochondrial markers reveal distinctiveness of a small population of bottlenose whales (Hyperoodon ampullatus) in the western North Atlantic. Mol Ecol 15: 3115-3129

Diggles BK, Ernst I (1997) Hooking mortality of two species of shallow-water reef fish caught by recreational angling methods. Mar Freshw Res 48:479-483

Elphinstone MS, Hinten GN, Anderson MJ, Nock CJ (2003) An inexpensive and high-throughput procedure to extract and purify total genomic DNA for population studies. Mol Ecol Notes 3:317-320

Krutzen M, Barre LM, Moller LM, Heithaus MR, Simms C, Sherwin WB (2002) A biopsy system for small cetaceans: darting success and wound healing in Tursiops spp. Mar Mamm Sci 18:863-878

Robbins WD (2006) Evaluation of two underwater biopsy probes for in situ collection of shark tissue samples. Mar Ecol Prog Ser 310:213-217

Spinsanti G, Panti C, Lazzeri E, Marsili L, Casini S, Frati F, Fossi CM (2006) Selection of reference genes for quantitative RT-PCR studies in striped dolphin (Stenella coeruleoalba) skin biopsies. BMC Mol Biol 7:32

Submitted: April 21, 2008; Accepted: June 25, 2008

Proofs received from author(s): September 14, 2008
Editorial responsibility: Hans Heinrich Janssen, Oldendorf/Luhe, Germany 